\title{
A METHOD TO CONTROL ENERGY COSTS OF ELECTRIC ENERGY SUBJECTS BY THE CRITERION OF ENERGY EFFICIENCY
}

\author{
V. G. Mokov ${ }^{1}$, mokhov50@mail.ru, \\ T. S. Demyanenko ${ }^{1}$, oop_flp@mail.ru \\ ${ }^{1}$ South Ural State University, Chelyabinsk, Russian Federation
}

\begin{abstract}
We consider a method to control the cost of electricity consumption of an industrial enterprise. The method is based on mathematical models and algorithms to control the consumption of electric energy according to the criterion of energy efficiency. A distinctive feature of the method is as follows. In order to forecast the electricity consumption and the amount of electricity supply, the method uses a mathematical model taking into account the separation of the maximum similarity sample into positive and negative values with different approximation equations. The method allows to develop managerial solutions to reduce the cost of electricity consumption by ensuring higher forecast accuracy and withdrawal of electric energy subjects from the penalty zone of the balancing Wholesale Electricity and Capacity Market of Russia. The obtained results are useful both for theoretical understanding of the functional features of the Wholesale Electricity and Capacity Market of Russia, and for practice: to plan industrial enterprises work in the energy market, to develop programs for energy saving, and to increase energy efficiency of the production.
\end{abstract}

Keywords: electricity consumption; control costs of an industrial enterprise; consumption forecasting; energy efficiency.

\section{Introduction}

Energy efficiency is an indicator characterized by the ratio of the beneficial effect of energy supply to the cost of obtaining the supply. At the same time, energy efficiency can be improved without increasing the beneficial effect with rational use of energy resources, i.e. with ensuring the same energy level of the enterprise and production, but with less energy consumption. If the energy is supplied to an enterprise by the Wholesale Electricity and Capacity Market (WECM) of Russia, then the purchase of electricity is carried out in the form of an auction, controlled by the System Operator, which imposes significant restrictions on the ways of financial savings. The auction is closed. Therefore, at the moment of submitting bids for amount of electrical energy to the System Operator, enterprises cannot be informed of the exact price in advance. The rules of operation on the WECM are organized as follows. The closer the price of a submitted bid to the equilibrium one, the more the probability that the enterprise will remain in the equilibrium market and will not enter the balancing market, where the purchase and sale prices of electrical energy are higher than the corresponding equilibrium prices. A similar situation arises in the case of planning the required amount of electricity. Namely, each subject of the WECM, both the producer and the consumer, strive to submit a bid with an amount as close as possible to the equilibrium one. Otherwise it is necessary to transfer to a balancing market. From time to time, enterprises need to submit a price-receiving bid, that is, the producer is ready to sell the amount at any price set by the market. It is logical to assume that a similar situation takes place when there are obvious production surpluses due to a 
strong deviation from the equilibrium price set by the System Operator. Let us give an example. Suppose that the equilibrium price is significantly lower than a bid submitted by a producer. Then the amounts of electricity generated by the producer are sold last, or are transferred to the balancing market, where the selling price is significantly lower than the equilibrium one [1,2]. Therefore, it is more profitable for the producer to submit a price-receiving bid, that is, to sell at the price set by the System Operator. However, a large number of price-receiving bids from producers leads to a reduction in tariffs in general, i.e. financially unprofitable situation [3]. The buyer submits a price-receiving bid, if there are errors in the planning of amounts. For example, consider the situation, when the buyer greatly underestimates the required amount. In this case, the buyer needs to buy the rest amount in the balancing market, where the purchase price is much higher than the equilibrium one.

Therefore, each electric energy subject is directly interested in the most accurate planning of the consumption amount and the cost of electricity. Indeed, financial savings are possible not only when energy consumption is reduced or saved, but also due to high precision of the production planning. The entire auction system of the System Operator is aimed at encouraging increased accuracy of submitted bids.

\section{Method to Control Energy Consumption of Electric Energy Subjects}

As is evident from the foregoing, there are the following requirements for the control method:

- high accuracy of forecasting the equilibrium price;

- high accuracy of electricity consumption amounts;

- operative decision on the tariffs and amounts submitted in bids to the System Operator for the purpose of production planning and financial savings at the expense of trading in the non-balancing market;

- ease of use of the control method in the form of a computer program;

- universality of the control method, that is, a unified system that allows to forecast all the indicators necessary for the enterprise;

- taking into account not only common external factors affecting changes in the price and amount of consumption, but also individual factors for each particular enterprise.

In order to ensure the correct implementation of the control method, both to the seller and the buyer, it is necessary to ensure the storage and accumulation of the following necessary information:

- data of the System Operator (the DAM tariff, the amount of electricity generation or consumption in the region or in the country as a whole, depending on the regional or federal level of the enterprise);

- data on common factors (ambient temperature, working and non-working days); 
- data on individual factors (consumption of a particular enterprise, generating capacity, etc.).

In order to implement the control method, we developed an economic-mathematical model for forecasting time series. The model is based on a sample of maximum similarity from historical data with a preliminary reduction of the time series to a stationary form, and the construction of different approximation equations for positive and negative levels of the series.

A time series is called stationary if the levels of the series are approximately homogeneous and have the form of continuous random oscillations around a certain average value. At the same time, both the average amplitude and the nature of these oscillations do not show significant changes over time.

In order to determine the stationarity of the time series, we use the Dickey-Fuller test (unit root test). The test is based on an estimate of the parameter $\lambda=\alpha_{1}-1$ of the equation $\tilde{Y}(t)=\lambda \cdot Y_{t-1}+\varepsilon_{t}$. Hypotheses: H0: $\lambda=0 ; \mathrm{H} 1: \lambda<0$. If the value of the Student's t-statistics for the parameter $\lambda$ is less than the lower threshold value of the DFstatistics, then the null hypothesis $\lambda=0$ (on the presence of the unit root $\alpha_{1}=1$ ) should be rejected, and an alternative hypothesis (on the stationarity of the process $Y_{t}$ ) should be accepted.

Consider a time series $Y_{t}=\left\{\left(y_{i}, t_{i}\right), i=1,2, \ldots, n\right\}$, where $y_{i}$ are time series levels, $t_{i}$ are time marks (moments or intervals of observations), $n$ is the number of time series levels. The initial time series is checked for stationarity by the Dickey-Fuller test. If the hypothesis $\mathrm{H} 1$ is confirmed, then a transition to a direct forecasting the series takes place. If the hypothesis $\mathrm{H} 0$ is confirmed, then the time series is artificially converted to a stationary form. To this end, the first and, if necessary, the second differences are found. If at this stage the stationarity of the series has not been achieved, then logarithm levels of the series are used. In the case of time series of electricity consumption and tariffs, the stationarity is achieved by finding the first differences in the levels of the series. However, one of the requirements to the control method is the universality of forecasting any data that the user will contribute to the system. Therefore, in order to reduce some data of a particular enterprise to a stationary form, double logarithm of levels may be necessary. The task of the user is to enter into the control system the required data in its original form. The task of the system is to convert the obtained data to the form provided the highest forecasting accuracy.

Since the time series of energy consumption is not stationary due to the presence of a trend, we need to integrate this series and, consequently, obtain levels of different signs.

The proposed forecasting algorithm is universal and can be used to forecast future values of both series with only positive or only negative values, as well as for series with different levels. The differences are only in the format of the input data and inverse operations on the convertation of the obtained forecasting value into the original format of the time series.

At the end of the forecasting algorithm, it is necessary to carry out the procedure of reverse replacements. That is, replace the forecasted values of the stationary series with the forecasted values of the original time series. The procedure is inverse of convertion of the series to stationarity. That is, if the series was converted to stationarity form by logarithm over the base of the exponent, then the obtained forecasted value is the exponent degree. 


\section{Algorithm of Forecasting Taking into Account External Factors}

Consider a time series $Y_{t}=\left\{\left(y_{i}, t_{i}\right), i=1,2, \ldots, n\right\}$, where $y_{i}$ are time series levels, $t_{i}$ are time marks (moments or intervals of observations), $n$ is the number of time series levels. Each time series level $y_{i}$ is connected with the values of external factors $x_{i 1}, x_{i 2}, \ldots, x_{i m}$. Each of the factors is a time series.

Let us describe the steps of the algorithm to forecast by a sample of maximum similarity with different approximation equations for positive and negative levels taking into account external factors.

Step 1. Determine a sample preceding the forecast.

The sample preceding the forecast is determined in each of the time series: dependent and factors. The sample length $M$ is determined by the model identification algorithm for the dependent time series $\tilde{Y}_{t}$. The following samples are determined.

$$
\begin{gathered}
\tilde{Y}_{t}^{M}=\tilde{Y}_{t_{n-1}}, \ldots, \tilde{Y}_{t_{n-1}-M}, \\
\tilde{X}_{t, 1}^{M}=\tilde{X}_{t_{n-1}, 1}, \ldots, \tilde{X}_{t_{n-1}-M, 1}, \\
\tilde{X}_{t, 2}^{M}=\tilde{X}_{t_{n-1}, 2}, \ldots, \tilde{X}_{t_{n-1}-M, 2}, \\
\tilde{X}_{t, m}^{M}=\tilde{X}_{t_{n-1}, m}, \ldots, \tilde{X}_{t_{n-1}-M, m} .
\end{gathered}
$$

Step 2. Divide the sample preceding the forecast.

Each of the obtained samples is divided into two subsamples: for positive and negative values.

Namely, $\tilde{Y}_{t}^{M}$ is divided into $\tilde{Y}_{t}^{M+}$ and $\tilde{Y}_{t}^{M-}$, and $\tilde{X}_{t, m}^{M}$ is divided into $\tilde{X}_{t, m}^{M+}$ into $\tilde{X}_{t, m}^{M-}$.

The length of each positive subsample is $v \in\{n-1-M ; n-1\}$, and the length of each negative one $-M-v \in\{n-1-M ; n-1\}$.

Step 3. Determine the approximation samples.

There exists the following algorithm to determine a sample $\tilde{Y}_{t-k}^{M}=\tilde{Y}_{t_{n-1}-k}, \ldots, \tilde{Y}_{t_{n-1}-k+M}$ with a reference point $k \in\left\{1,2, \ldots, t_{n-1}-M\right\}$ of length $M$ in the time series $\tilde{Y}_{t}$.

1. Set the lag be equal to 1 and consecutively compare the values of the sample $\tilde{Y}_{t}^{M}$ with the values of the time series $\tilde{Y}_{t}$.

2. Calculate the value of the correlation coefficient for each shift.

Choose the greatest value of the obtained correlation coefficients and determine the lag $k$ corresponded to the value.

The lengths of the time series of factors and the indicator are the same. Therefore, in each of the series of factors, there is a sample $\tilde{X}_{t-k, m}^{M}=\tilde{X}_{t_{n-1}-k, m}, \ldots, \tilde{X}_{t_{n-1}-k+M, m}$ of length $M$ and with a reference point $k$.

Step 4. Determine forecasting samples.

If it is necessary to forecast $p$ levels of the time series, then the forecasting sample is the segment of the time series that follows the approximation sample of length $p$. Therefore, for the series of indicator, the approximation sample is $\tilde{Y}_{t-k}^{M}$, and the forecasting sample is $\tilde{Y}_{t}^{p}=\tilde{Y}_{t-k+M+1}, \ldots, \tilde{Y}_{t-k+m+1+p}$. For time series of factors, the forecasting sample is $\tilde{X}_{t, m}^{p}=\tilde{X}_{t-k+M+1, m}, \ldots, \tilde{X}_{t-k+m+1+p, m}$.

Step 5. Divide approximation samples. 
The approximation sample of the indicator $\tilde{Y}_{t-k}^{M}$ is divided into two subsamples: $\tilde{Y}_{t-k}^{M+} \geq 0$ for positive values of the sample, and $\tilde{Y}_{t-k}^{M-}<0$ for negative values of the sample. Factor approximation samples $\tilde{X}_{t-k, m}^{M}$ are divided into $\tilde{X}_{t-k, m}^{M+} \geq 0$ and $\tilde{X}_{t-k, m}^{M-}<0$.

Sample lengths for each time series are $q \in\{n-1-M ; n-1\}$ and $M-q \in\{n-1-M ; n-1\}$ for positive and negative values, respectively.

Step 6. Divide forecasting samples.

The forecasting sample $\tilde{Y}_{t}^{p}$ is divided into two subsamples: $\tilde{Y}_{t}^{p+}$ for positive values of the sample, and $\tilde{Y}_{t}^{p-}$ for negative values of the sample. Factor approximation samples $\tilde{X}_{t, m}^{p}$ are divided into $\tilde{X}_{t, m}^{p+} \geq 0$ and $\tilde{X}_{t, m}^{p-}<0$.

Sample lengths for each time series are $w \in\{t-K+m+1 ; t-k+m+1+p\}$ and $p-w \in\{t-K+m+1 ; t-k+m+1+p\}$ for positive and negative values, respectively.

Step 7. Supplement the divided approximation samples with zeros.

By analogy with the approximation model without taking into account external factors, all obtained approximation samples (including samples of external factors) are complemented with zeros up to length $M$.

Step 8. Construct approximation equations for positive and negative values of the approximation sample taking into account external factors.

On the basis of the obtained approximation samples $\tilde{Y}_{t-k}^{M+}, \tilde{Y}_{t-k}^{M-}, \tilde{X}_{t-k, m}^{M+}, \tilde{X}_{t-k, m}^{M-}$, construct the approximation equations

$$
\begin{aligned}
& \hat{\tilde{Y}}_{t}^{M+}=\alpha_{m+1}^{+} \tilde{X}_{t-k, m}^{M+}+\alpha_{m}^{+} \tilde{X}_{t-k, m-1}^{M+}+\ldots+\alpha_{2}^{+} \tilde{X}_{t-k, 1}^{M+}+\alpha_{1}^{+} \tilde{Y}_{t-k}^{M+}+\alpha_{0}^{+}, \\
& \hat{\tilde{Y}}_{t}^{M-}=\alpha_{m+1}^{-} \tilde{X}_{t-k, m}^{M-}+\alpha_{m}^{-} \tilde{X}_{t-k, m-1}^{M-}+\ldots+\alpha_{2}^{-} \tilde{X}_{t-k, 1}^{M-}+\alpha_{1}^{-} \tilde{Y}_{t-k}^{M+}+\alpha_{0}^{-}
\end{aligned}
$$

where $\alpha_{i}^{+}$and $\alpha_{i}^{-}$are the approximation coefficients, $i \in\{1,2, \ldots, m\}$. The values of the approximation coefficients should be such that

$$
\begin{aligned}
& \sigma^{2}=\sum_{t=0}^{M-1}\left(\tilde{Y}_{t+i}^{M+}-\hat{\tilde{Y}}_{t+i}^{M+}\right)^{2} \rightarrow \min , \\
& \sigma^{2}=\sum_{t=0}^{M-1}\left(\tilde{Y}_{t+i}^{M-}-\hat{\tilde{Y}}_{t+i}^{M-}\right)^{2} \rightarrow \min
\end{aligned}
$$

that is, the squares of deviations of model values from real values should be minimal.

The values of the approximation coefficients are found using the method of least squares.

Step 9. Obtain a forecast.

In order to obtain a forecast, each value of the subsample $\tilde{Y}_{t}^{p+}$ is approximated using the following equation:

$$
\hat{\tilde{Y}}_{t}^{M+}=\alpha_{m+1}^{+} \tilde{X}_{t-k, m}^{M+}+\alpha_{m}^{+} \tilde{X}_{t-k, m-1}^{M+}+\ldots+\alpha_{2}^{+} \tilde{X}_{t-k, 1}^{M+}+\alpha_{1}^{+} \tilde{Y}_{t-k}^{M+}+\alpha_{0}^{+} I^{M+}
$$

and each value of the subsample $\tilde{Y}_{t}^{p-}$ is approximated using the equation

$$
\hat{\tilde{Y}}_{t}^{M-}=\alpha_{m+1}^{-} \tilde{X}_{t-k, m}^{M-}+\alpha_{m}^{-} \tilde{X}_{t-k, m-1}^{M-}+\ldots+\alpha_{2}^{-} \tilde{X}_{t-k, 1}^{M-}+\alpha_{1}^{-} \tilde{Y}_{t-k}^{M+}+\alpha_{0}^{-} I^{M-} .
$$

The obtained forecasting values are arranged in the same order in which the corresponding values were in the sample. 


\section{Conclusion}

Due to the specifics of the domestic energy market organization, the imperfection of instrumental forecasting methods used by industrial enterprises to work on the WECM leads to deviations in bids for the supply and purchase of electric energy and satisfaction of the bids on the balancing market of the WECM, whose tariffs are significantly higher than DAM ones. The current rules of the WECM work determine the relevance and practical significance of research aimed at developing methodological support to control the energy costs of industrial enterprises by the energy efficiency criterion. To this end, the control methods use long-term and short-term forecasting algorithms for electricity consumption. The algorithms adequately describe the behavior of the time series of the WECM data. The series has high speed of calculation of forecasting values and the accuracy of forecasting the amount of electricity consumption, which is comparable with the accuracy of the similar autoregressive models.

\section{References}

1. Dzyuba A. P. Management of Energy Consumption of the Industrial Enterprises. PhD Thesis. Chelyabinsk, 2014. (in Russian)

2. Isaev A. S., Oshurkov M. G. Perspective Assessment of Daily Production Schedules of the Enterprise - the Subject of OREM. News of the Tula State University. Technical sciences, 2017, issue 12, part 1, pp. 75-81. (in Russian)

3. Chebotaryova G. S. Methodical Tools of Assessment of Investment Attractiveness of the Energy-Generating Company. PhD Thesis. Ekaterinburg, 2016. (in Russian)

Veniamin G. Mokhov, DSc (Economics), Professor, Department of Mathematical and Computer Modelling, South Ural State University (Chelyabinsk, Russian Federation), mokhov50@mail.ru.

Tatyana S. Demyanenko, Department of Mathematical and Computer Modelling, South Ural State University (Chelyabinsk, Russian Federation), oop_flp@mail.ru.

Received February 16, 2019. 
УДК $621.31: 339.1+519.86+621.31(470.5)$

\title{
МЕТОД УПРАВЛЕНИЯ ЭНЕРГОЗАТРАТАМИ СУБЪЕКТОВ ЭЛЕКТРОЭНЕРГЕТИКИ ПО КРИТЕРИЮ ЭНЕРГОЭФФЕКТИВНОСТИ
}

\author{
В. Г. Мохов, Т. С. Демъяненко
}

\begin{abstract}
В статье рассмотрен метод управления затратами на электропотребление промышленного предприятия на основе математических моделей и алгоритмов управления потреблением электрической энергии по критерию энергоэффективности. Отличительной особенностью метода является учет в математической модели при прогнозировании электропотребления и объемов электроснабжения разделения выборки максимального подобия на положительные и отрицательные значения с разными уравнениями аппроксимации. Использование предлагаемого механизма дает возможность разработать управленческие решения по снижению затрат на электропотребление за счет обеспечения более высокой точности прогноза и ухода субъектов электроэнергетики из зоны штрафных санкций балансирующего оптового рынка электрической энергии и мощности России. Полученные результаты исследования полезны как для теоретического осмысления особенностей функционирования Оптового рынка электрической энергии и мощности России, так и для практиков - промышленных предприятий при планировании их работы на энергетическом рынке и разработке программ энергосбережения и повышения энергоэффективности производства.

Keywords: электропотребление; управление затратами промышленного предприятия; прогнозирование обгема потребления; энергоэффективность.
\end{abstract}

\section{References}

1. Дзюба, А. П. Управление энергозатратами промышленных предприятий: дис. ... канд. экон. наук / А. П. Дзюба. - Челябинск, 2014.

2. Исаев, А. С. Перспективная оценка суточных графиков нагрузки предприятия субъекта ОРЭМ / А. С. Исаев, М. Г. Ошурков // Известия Тульского государственного университета. Технические науки. - 2017. - Вып. 12, ч. -1. - С. 75-81.

3. Чеботарева, Г. С. Методический инструментарий оценки инвестиционной привлекательности энергогенерирующей компании: дис. ... канд. экон. наук / Г. С. Чеботарева. - Екатеринбург, 2016.

Мохов Вениамин Геннадъевич, доктор экономических наук, профессор, профессор кафедры математического и компьютерного моделирования, ЮжноУральский государственныц университет (Челябинск, Российская Федерация), mokhov50@mail.ru.

Демьяненко Татьяна Сергеевна, старший преподаватель кафедры математического и компъютерного моделирования, Южно-Уральский государственныи университет (Челябинск, Российская Федерачия), оор_flp@таil.ru.

Поступила в редакиию 16 февраля 2019 г. 